\section{STAHLIANTHUS INVOLUCRATUS (KING EX BAKER) CRAIB EX LOES.: A NEW RECORD TO THE FLORA OF MIZORAM, INDIA}

\section{Ranbir Singh Rathi ${ }^{1}$, Kanakasabhapathi Pradheep ${ }^{2}$, Somnath Roy ${ }^{3}$, Sanjeev Kumar Singh ${ }^{4}$ \& Anup Kumar Misra ${ }^{5}$}

${ }^{1}$ ICAR-National Bureau of Plant Genetic Resources (ICAR-NBPGR) Regional Station, Plandu, Ranchi, Jharkhand 834010, India ${ }^{2}$ ICAR-NBPGR, Ministry of Agriculture and Farmers Welfare (Govt. of India), Pusa Campus, New Delhi 110012, India

3,4,5 ICAR-NBPGR Regional Station, Umiam, Meghalaya 793103, India ${ }^{1}$ ranbirsinghrathi@gmail.com, ${ }^{2}$ k.pradheep@icar.gov.in (corresponding author), ${ }^{3}$ sroypbr@gmail.com,

${ }^{4}$ sanjeevs99@rediffmail.com, ${ }^{5}$ akmisra@yahoo.com

Stahlianthus Kuntze (Family Zingiberaceae, Tribe Zingibereae) consists of seven species distributed from the eastern Himalaya to southern China and IndoChina, of which only a reasonably widespread species $S$. involucratus (King ex Baker) Craib ex Loes., is reported from India (Sanoj et al. 2008; WCSP 2015). Stahlianthus involucratus was originally described under the genus Kaempferia L. (as Kaempferia involucrata King ex Baker) by J.G. Baker in the Flora of British India based on the collections from Rangirum (in Darjeeling) and Assam (Hooker 1894). Its transfer under Stahlianthus was first suggested by W.G. Craib while transferring Kaempferia macrochlamys Baker under Stahlianthus, with a remark "To Stahlianthus also being $K$. involucrata, King ex Baker and probably K. Andersoni, Baker" (Craib, 1912); Loesener (1930) made formal combinations and Smith (1991) chose the lectotype. Until recently it had been reported to occur in the states of Assam, Meghalaya, Nagaland and West Bengal in India (Smith 1991; Sanoj et al. 2008).

This medicinally important species was collected during the year 2000 from wild habitats in Kolasib District of Mizoram under the name "Curcuma sp." (owing to its superficial resemblance to Curcuma species). It adapted well in the field genebank of ICAR-

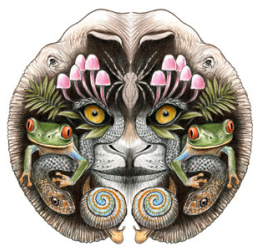

ISSN 0974-7907 (Online) ISSN 0974-7893 (Print)

\section{OPEN ACCESS}

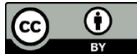
NBPGR, Regional Station, Umiam,

Meghalaya, and is being maintained and botanically studied thereafter. After critical study with the help of floristic literature, online herbarium at $E, K, P$ and $P E$, the germplasm under question was identified as $S$. involucratus (King ex Baker) Craib ex Loes., a taxon not earlier reported from the state of Mizoram; hence it forms a new distribution record for the state.

\section{Stahlianthus involucratus}

(King ex Baker) Craib ex Loes. in Engl. \& Prantl, Nat. Pflanzenfam., ed. 2. [Engler \& Prantl] 15a: 564. 1930; T.L. Wu \& K. Larsen in C.Y. Wu \& H.P. Raven, Fl. China 24: 368. 2000. Kaempferia involucrata King ex Baker in J.D. Hooker, Fl. Brit. India 6: 221. 1890. Stahlianthus involucratus (King ex Baker) R.M. Sm., Edinb. J. Bot. 48(1): 24. 1991. (Image 1)

Plant: $40-50 \mathrm{~cm}$ high, pseudostem absent. Rhizomes: tuberous, $1 \mathrm{~cm}$ diameter, brownish-yellow inside, strongly fragrant. Roots: white, leads to napiform tubers at tip; tubers $1.5-1.6 \times 0.8 \mathrm{~cm}$. Leaves: $4-5$ in number, suberect; petiole 10-17 cm long; lamina green, glabrous, membranous, obovate-oblong or lanceolate, $15-20 \times 2.5-3 \mathrm{~cm}$, tip acuminate. Inflorescence: lateral, capitate; peduncle 3-10 cm long; 6-8 flowered, flowers surrounded by two green bracts fused at the

DOI: http://dx.doi.org/10.11609/jott.1841.8.3.8629-8631

Editor: Anonymity requested.

Date of publication: 26 March 2016 (online \& print)

Manuscript details: Ms \# 1841 | Received 24 February 2015 | Final received 11 December 2015 | Finally accepted 22 February 2016

Citation: Rathi, R.S., K. Pradheep, S. Roy, S.K. Singh \& A.K. Misra (2016). Stahlianthus involucratus (King ex Baker) Craib ex Loes.: a new record to the flora of Mizoram, India. Journal of Threatened Taxa 8(3): 8629-8631; http://dx.doi.org/10.11609/jott.1841.8.3.8629-8631

Copyright: () Rathi et al. 2016. Creative Commons Attribution 4.0 International License. JoTT allows unrestricted use of this article in any medium, reproduction and distribution by providing adequate credit to the authors and the source of publication.

Funding: This work was funded by the parental institute i.e. ICAR-NBPGR, New Delhi.

Conflict of Interest: The authors declare no competing interests.

Acknowledgments: The Head, Division of Plant Exploration and Germplasm Collection, ICAR-NBPGR and the Director, ICAR-NBPGR for their guidance throughout the period of study. Acknowledgements are also due to germplasm collection team of ICAR-NBPGR, New Delhi/ Shillong. 

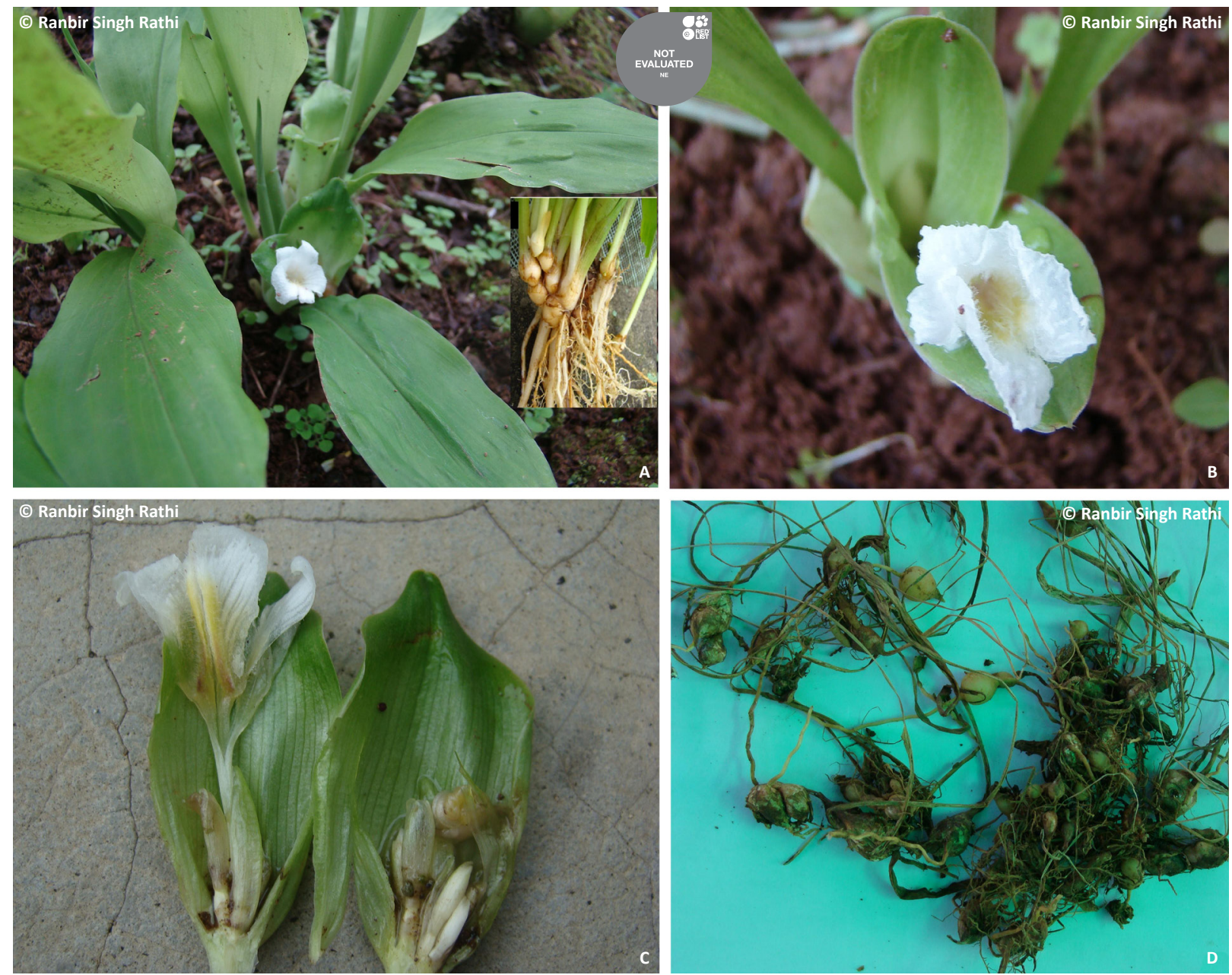

Image 1. Stahlianthus involucratus

A - Habit - flowering plant (inset: rhizome with roots at early stage); B - Inflorescence showing flower; C - Exposed inflorescence showing translucent bracteoles, corolla tube and labellum; D - Rhizomes, tubers and roots at maturity

base yielding campanulate outlook. Bracts: $4-4.5 \times$ 2-2.5 cm, leathery, green, glabrous with small brown glandular spots, apex broadly acuminate. Bracteoles: linear, $1.5 \mathrm{~cm}$, membranous, translucent. Flowers: $4 \mathrm{~cm}$ long, one opens at a time. Calyx: tubular, $1-1.2 \mathrm{~cm}$ long. Corolla: tube $2-2.5 \mathrm{~cm}$ long, white, pubescent at base inside, distally 3-lobed, lobe $1.2 \mathrm{~cm}$, dorsal one apiculate. Lateral staminodes: petaloid, oblanceolate, $1.6-2 \times 0.4 \mathrm{~cm}$. Labellum: white spathulate-obovate, with a central yellow blotch, $2 \times 1.4 \mathrm{~cm}$, hairy inside, apex emarginated or shortly bifid. Filaments: $2 \mathrm{~mm}$, flat; anthers $4 \mathrm{~mm}$ long. Ovary: ovoid, $3 \mathrm{~mm}$, 3-loculed; ovules many. Style: linear, white, glabrous. Stigma: cupshaped, white. Seeds: globose.

Phenology: Flowering started from the last week of April and continued until mid-June at Umiam (Meghalaya) conditions.

Ecology: Among natural conditions in Mizoram, it grows occasionally in shaded forest areas.

Distribution: Bangladesh, China, India, Myanmar and Thailand (Wu \& Larsen 2000; WCSP 2015). Its wild occurrence in Cambodia, Laos and Vietnam needs verification, although reported; India: Assam, Meghalaya, Mizoram, Nagaland and West Bengal (Darjeeling).

Germplasm maintained: DMRK-52 (IC278054), 29 November 2000 (live plant), North Thingdawl, Kolasib District, Mizoram, India (Image 2); living collection maintained at field genebank, ICAR-NBPGR Regional Station, Umiam, Meghalaya.

Notes: It has $2 n=22$, equal to that of Curcuma species. The plant is hardy and propagates through rhizomes, and adapts well under partial shade conditions. Plants maintained with a spacing of $30 \times 20 \mathrm{~cm}$ over raised bed yielded 70-150 g fresh rhizomes/individual. Rhizomes have medicinal and aromatic properties that can help 


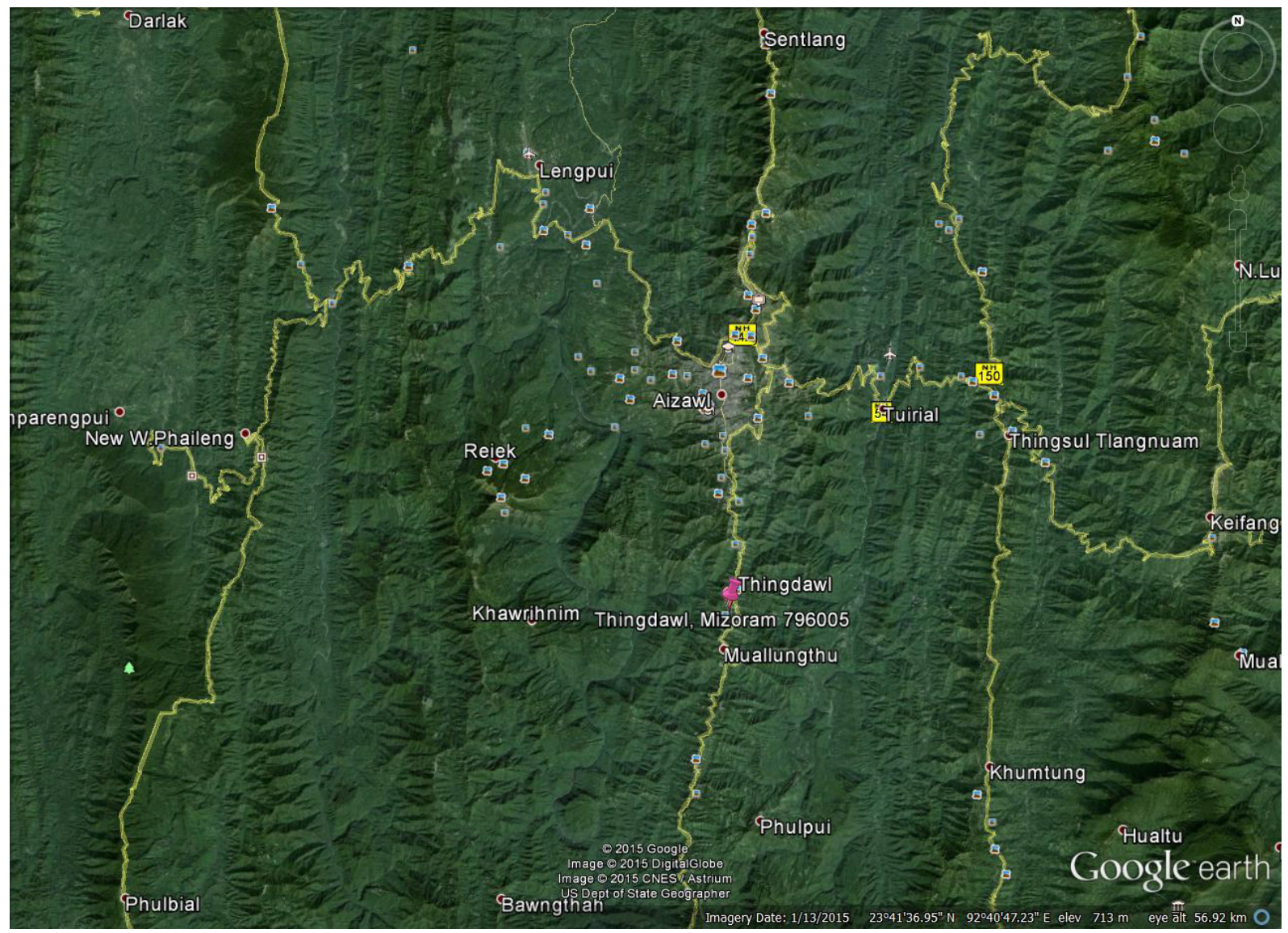

Image 2. Site (indicated in pink pegs) of Stahlianthus involucratus collection in Kolasib District, Mizoram

in the treatment of inflammation and pain. Rhizomes are also useful in arresting bleeding, treating bleeding, snake bites, menorrhagia, hematemesis, among others (Pingsusaen et al. 2015).

The closeness of this genus with Kaempferia and Curcuma, as evident from the frequent transfer of its species into these genera, and recently proved through molecular analysis (Ngamriabsakul et al. 2003; Záveská et al. 2012), shows its value as germplasm useful in the breeding (of crop species belonging to the above two genera), besides its medicinal value. There is an urgent need to collect the diverse germplasm across habitats for ex situ conservation as well as assessing the biochemical and medicinal properties.

\section{References}

Craib, W.G. (1912). Contributions to the flora of Siam-II. Bulletin of Miscellaneous Information, No. 10. Royal Botanic Gardens, Kew, 397-434pp.

Hooker, J.D. (1894). The Flora of British India - Vol. 6. L. Reeve \& Co., London, 792pp.

Loesener, T. (1930). Zingiberaceae, pp. 541-640. In: Engler, A. \& K. Prantl (eds.). Die Natürlichen Pflanzenfamilien, Second Edition - Vol. 15a. W. Engelmann, Leipzig.

Ngamriabsakul, C., M.F. Newman \& Q.C.B. Cronk (2003). The phylogeny of tribe Zingibereae (Zingiberaceae) based on ITS (nrDNA) and trnL-F (cpDNA) sequences. Edinburgh Journal of Botany 60(3): 483-507; http://dx.doi.org/10.1017/S0960428603000362

Pingsusaen, P., P. Kunanusorn, P. Khonsung, N. Chiranthanut, A. Panthong \& C. Rujjanawate (2015). Investigation of antiinflammatory, antinociceptive and antipyretic activities of Stahlianthus involucratus rhizome ethanol extract. Journal of Ethnopharmacology 162: 199-206; http://dx.doi.org/10.1016/j. jep.2014.10.060. Epub 2014 Nov 21

Sanoj, E., V.P. Thomas, M. Sabu \& T.R. Kumar (2008). Stahlianthus involucratus (King ex Baker) R.M. Smith (Zingiberaceae): A new generic record for India. Folia Malaysiana 9(1): 43-50.

Smith, R.M. (1991). Notes relating to the Flora of Bhutan: XVII. Zingiberaceae. Edinburgh Journal of Botany 48(1): 23-25; http:// dx.doi.org/10.1017/S0960428600003565

WCSP (2015). World Checklist of Selected Plant Families. Facilitated by the Royal Botanic Gardens, Kew. Published on the Internet; http:// apps.kew.org/wcsp/. Accessed 19 January 2015

Wu, T.L. \& K. Larsen (2000). Zingiberaceae, pp. 322-378. in: Raven, P.H. \& T.L. Wu (eds.). Flora of China, Vol-24. Science Press, Beijing, and Missouri Botanical Garden, St. Louis (http://www.efloras.org/ florataxon.aspx?flora_id=2\&taxon_id=131173 Electronic version accessed 15 February, 2015).

Záveská, E., T. Fér, O. Šída, K. Krak, K. Marhold \& J. Leong-Škorničková (2012). Phylogeny of Curcuma (Zingiberaceae) based on plastid and nuclear sequences: Proposal of the new subgenus Ecomata. Taxon 61(4): 747-763. 